\title{
Article Review \\ Restoration of polluted soils by means of microbial and enzymatic processes
}

\author{
Liliana Gianfreda ${ }^{1}$, María Luz Mora ${ }^{2}$, María Cristina Diez ${ }^{3}$ \\ ${ }^{1}$ Dipartimento di Scienze del Suolo, della Pianta e dell' Ambiente, Università di Napoli \\ Federico II, Portici, Napoli, Italy \\ ${ }^{2}$ Departamento de Ciencias Químicas .Universidad de La Frontera, Temuco, Chile \\ ${ }^{3}$ Departamento de Ingeniería Química, Universidad de La Frontera, Temuco, Chile
}

\section{Restauración de suelos contaminados por medio de procesos microbiológicos y enzimáticos}

\section{INTRODUCTION}

In the last years, a high number of highly toxic compounds have been released into the environment because of several industrial and/or agricultural activities. Typical organic chemicals include pesticides, fuels, solvents, alkanes, polycyclic aromatic hydrocarbons (PAHs), nitrogen and phosphorus compounds, explosives, and dyes while inorganic contaminants are mainly represented by toxic heavy metals.

Contamination of soil, surface and ground water by organic pollutants is a problem of great environmental concern in several countries. Furthermore, a complex pollution including more than one pollutant and also toxic metals may accumulate in the environment thus being a point of major concern for both a toxicological risk assessment of contaminated field sites and to study the feasibility of bioremediation technologies to remediate contaminated soils.

Intrinsic biodegradation is one of the natural attenuation phenomena, which may occur at the contaminated soil and contribute to its remediation (Figure 1). Indeed, most of polluting chemicals have been proven to be transformed by microbial organisms (Alexander, 1985; Cerniglia, 1992; Alexander, 1994). Their susceptibility to biodegradation may, however, change drastically, depending on several factors related to the chemical and physical properties of both the chemical and the environment in which they are present.

Although much experimental evidence supports the capability of microorganisms to biodegrade organic pollutants, several sites are still strongly contaminated, indicating a high persistence of these compounds under field conditions.

Several strategies have been devised to remediate and restore polluted environments: physical and chemical methods and biological approaches, requiring the involvement of biological agents (Adriano et al., 1999; Alexander, 1985, 19994; Bollag and Liu, 1990; Bollag and Bollag, 1995; Bouwer and Zender, 1993; Cerniglia, 1992; Edgehill, 1999; Edgehill et al., 1991, Gevao et al., 2000; 


\section{Intrinsic biodegradation (active endogenous microorganisms)}

\section{Chemical transformations (hydrolysis, oxidation, polymerization)}

Stabilization

(binding and sequestration by clays and humus)

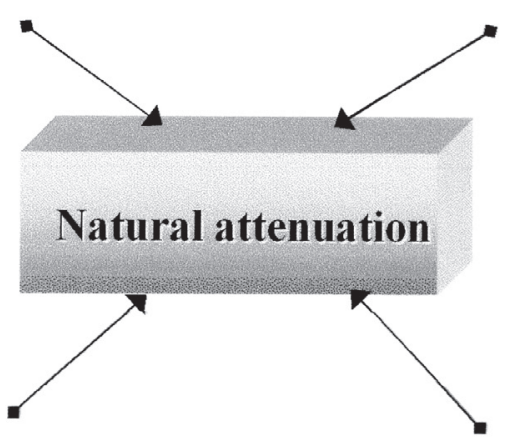

Volatilization
Dispersion
Dilution

Figure 1 Natural attenuation phenomena of organic pollutants in soil

Gianfreda and Nannipieri, 2001; Kamer, 1993; Harayama, 1997; Iwamoto and Nasu, 2001; Smith and Mason, 1999; Suthersan, 1999; Wilson and Jones, 1993). These latter techniques may be utilized in situ, i.e. in the contaminated place itself, offering numerous advantages over ex situ technologies. The first ones can be done on site, eliminating transportation costs, are less expensive, can be applied to diluted and widely diffused contaminants, and minimize dangerous manipulations of the environment. While in ex situ techniques, the treatments removing the contaminants occur at a separate treatment facility (Hamer, 1993).

Bioremediation, either as a spontaneous or as a managed strategy, is usually considered a softer and cleaner methodology than the traditional techniques for the clean-up of polluted systems. The main agents involved in bioremediation processes are plants, microorganisms, enzymes and plantmicroorganisms associations (Bumpus, 1993; Dec and Bollag, 1994; Durán et al., 2002; Harvey et al., 2002; Hood, 2002; Karam and Nicell, 1997, Korda et al., 1997; Liu and
Sulfita 1993; Lynch, 2002; Nannipieri and Bolag, 1991; Nicell, 2001; Pointing, 2001; Reddy, 1995; Roper et al., 1996; Siciliano and Germida, 1998; Smith and Mason, 1999; Sutherland et al., 2002; Walton et al., 1994). All are effective agents in the transformation of organic pollutants because their enzymatic components are powerful catalysts, able to extensively modify structure and toxicological properties of contaminants or to completely mineralize the organic molecule into innocuous inorganic end products. Furthermore, enzymes carry out processes for which no efficient chemical transformations could have been devised.

The purpose of soil bioremediation is "not only to enhance the timely degradation, transformation, remediation or detoxification of pollutants by biological means, but also to protect soil quality" (Adriano et al., 1999). A very important point is to understand the hazard pollutant present, the subsequent pollutant fate in the environment and the intensity of the pollution to developing suitable biological methods for remediation. 
Consequently, a successful implementation of a bioremediation technology requires a multidisciplinary approach (Blackburn and Hafker, 1993; Boopathy, 2000). Basic knowledge in microbiology, biochemistry, physiology, ecology and genetics is needed to find the most suitable contaminantdegrading organism, to determine the optimal conditions for growth of organisms and biotransformation of pollutants, to monitor for unwanted by-products (Chen et al, 1999, Edgehill, 1999, Edgehill et al., 1991; Gianfreda and Nannipieri, 2001; Iwamotoand Nasu, 2001; Liu and Sulfita, 1993; Smith and Mason, 1999; Suthersan, 1999). On the other hand, contributions by environmental chemists, engineers, hydrogeologists, and soil scientists are necessary to design a system well tailored to the contamination problem and possessing optimal environmental conditions for the action of the decontaminating organism. Furthermore, an economical evaluation of the overall bioremediation program by economists is also required to assess the use of the remedation technique as a competitive and alternative decontamination strategy (Caplan, 1993).

\section{Degradation of organic pollutants by soil microorganisms}

An organic pollutant may be biologically (microbially or enzymatically) degraded in soil. The degradative efficiency of biological processes, however, depends on the biodegradability of the contaminants. i.e. its susceptibility to be degraded in less toxic products, which is strongly influenced by its chemical structure, concentration and properties and by environmental conditions (Wilson and Jones, 1993). The most common contaminants can be classified on the basis of their biodegradability. Pollutants like simple hydrocarbons C1-C15, alcohols, phenols, amines, acids, esters, and amides are very easily biodegraded. By contrast, polychlorinated biphenyls (PCBs), polycyclic aromatic hydrocarbons (PAHs) as well as pesticides are very difficult biodegradable. Usually the most complex is the chemical structure; the less biodegradable is the compound.

Three basic principles concur to assure a successful, intrinsic bioremediation of sites contaminated by organic pollutants: the biochemistry and the bioactivity of the process, and the bioavailability of the pollutants to microbial degradation (Bollag and Bollag, 1985, Bouwer and Zehnder, 1993).

Biodegradation until complete mineralization to $\mathrm{CO}_{2}$ and water may be brought about by a large diversity of bacteria and fungi under both aerobic and anaerobic conditions (Alexander, 1985; Bouwer and Zehnder, 1993, Cerniglia, 1992; Harayama, 1997; Korda et al., 1997). Specific biochemical pathways have been developed by specific classes of bacteria and fungi, which have adapted their enzymatic and metabolic complements for the use of these complex molecules as energy and carbon sources. Co-metabolic routes with formation of intermediates, often less harmful than their parent compounds may be also carried out.

In order to be biodegraded, contaminants must interact with enzymatic systems in the degrading organisms. If soluble, they can easily enter cells, if insoluble, they must be transformed into soluble or easily cellavailable products. The first effective step for cell-transformation of insoluble substances, including xenobiotics and even plastic materials, is usually the reaction catalyzed by ecto- and extracellular enzymes (i.e. enzymes acting outside but in proximity or far from their generating cells, respectively), which are deliberately released by the cells into their nearby environment. The process can be quite rapid for some natural compounds like cellulose or very slow for many xenobiotics.

In the degradation of several polycyclic aromatic hydrocarbons, one of the main biochemical reactions, taking place under 
aerobic conditions, is the initial activation of the aromatic ring, brought about by the concomitant action of oxygenases and molecular oxygen (Cerniglia 1992; Bouwer and Zehnder, 1993). A phenol, such as catechol, is usually produced as a common intermediate product. This compound may be either completely degraded by a further microbial action or transformed to soluble and insoluble polymeric products by biotic (phenoloxidases) and abiotic ( $\mathrm{Mn}$ and $\mathrm{Fe}$ oxides) catalysts (Naidja et al., 1999).

Halogenated organic compounds are often pollutants in soil being added as herbicides, insecticides, fungicides, solvents and other products. Their recalcitrance depends on the number, type and position of the halogen substituents. The cleavage of the carbon-halogen bond makes these compounds more degradable and it is carried out by specific intracellular enzymes called dehalogenases which differ for their mechanisms of reaction (Fetzner et al, 1994; Gianfreda and Bollag, 2002). Seven different dehalogenation mechanisms have been recognized including reductive, oxygenolytic, hydrolytic, and thiolytic dehalogenation, dehydrohalogenation and hydratation and intramolecular substitution. All these mechanisms usually lead to products less toxic than their parent compound (Gianfreda and Bollag, 2002).

Intrinsic contaminant biodegradability, contaminant concentration, environmental $\mathrm{pH}$ and temperature, and availability of electron acceptors are the main factors that affect the biochemistry of a pollutant microbial degradation (Blackburn and Hafker, 1993).

The concentration of the contaminant may impose limits to the biodegradation at both ends of the scale. A high toxicity or a low bioconversion, arising at high or low concentration levels respectively, may inhibit contaminant biodegradation (Pirt, 1965). An alkaline $\mathrm{pH}$ as well as a mild temperature usually favours microbial growth, and consequently contaminant degradation.

The presence of appropriate redox conditions will determine which redox regime will occur, and, in turn, which kind of substance will be degraded. An aerobic transformation is usually the most effective for a complete degradation of the majority of pollutants. When oxygen amount is limited, as at very high depth in soil, degradation may even occur, because various microbial communities are able to be active under anaerobic conditions and to use alternate acceptors. In the absence of oxygen, nitrate, $\mathrm{Mn}$ and Fe oxides, and sulphate may act as suitable electron acceptors.

Bioavailability, i.e. the accessibility of molecules to microbial attack or, in general, to any other biological agent, for being degraded (Alexander, 2000), depends on both soil and contaminant properties. Several factors may affect the bioavailability of an organic chemical and these include soil properties and molecular structure, concentration and physico-chemical characteristics of the contaminant (KogelKnabner et al., 2000; Gevao et al, 2000; Luecking et al., 2000). A pollutant can be adsorbed by organic and inorganic components of the solid phase of soil, be transported by the soil aqueous phase, and this amount will depends on water solubility of the pollutant, or be volatilized in the gaseous phase of soil. However, even if the pollutants characteristics and concentration and soil properties are known, it may be difficult to foresee the behaviour of the contaminant in soil. For example, water insoluble compounds can be adsorbed by water soluble soil organic components and, thus, be transported by the aqueous phase of soil.

The accessibility of the contaminant to microbial agents is also reduced with aging (Alexander, 2000, Gevao et al., 2000; Ramaswami et al., 1997). Sequestration of molecules from diffusion into the solid portion of soil as well as their entry into 
nanopores are two processes that may occur with time. Both of them convert compounds from a bioavailable to a not bioavailable form.

Water solubility, which is strictly related to the molecular complexity of both single chemical and chemical mixture, affects the concentration of the pollutant in the aqueous phase and, consequently, its availability to microbial uptake.

Localized environmental conditions may be unfavourable to the biodegradation process and affect the bioactivity of the process that is the possibility to optimise the biological activity and to overcome all factors negatively affecting microbial degradation of the organic contaminant. Both physical (i.e. organic sorption to soil surfaces, entrapment of organics in small pores, poor distribution of electron acceptors, lack of moisture) and biological (i.e. lack of metabolic capability, lack of balanced nutrient supplies, toxicity of contaminants, intolerance to $\mathrm{pH}$, salts, or metals) constraints may limit partially or totally the degradation of pollutants and negatively affect the bioactivity of the process (Table 1).

These constraints should be overcome to enhance the biodegradation of organic pollutants and favour an in-situ bioremediation. Suitable strategies may be implemented to improve the bioactivity of a bioremediation process (Table 2).

In the case of pollutants, which have very low water solubility, application of surfactants is often required to facilitate their accessibility to microorganisms. In spite of the advantages presented by application of these latter, some disadvantages may compromise an effective utilization of such a compound (Table 3).

When biostimulation of the indigenous microflora present at the contaminated site is not effective, a "bioaugmentation" strategy may be adopted. It consists in the inoculation of proper microbial strains and/ or consortia (i.e. capable of degrading the target pollutant) into the system (Edgehill, 1999).

\section{Table 1 Constraints to Microbial-Based Remediation of Contaminated Soil}

\begin{tabular}{|c|l|}
\hline \multirow{3}{*}{ Physical } & $\begin{array}{l}\text { Organic sorption to soil surfaces. } \\
\text { Entrapment of organics in small pores. } \\
\text { Poor distribution of electron acceptors. } \\
\text { Lack of moisture. }\end{array}$ \\
\hline Biological & $\begin{array}{l}\text { Lack of metabolic capability. } \\
\text { Lack of balanced nutrient supplies. } \\
\text { Toxicity of contaminants. } \\
\text { Intolerance to } \mathrm{pH}, \text { salts, or metals. }\end{array}$ \\
\hline
\end{tabular}


Bioaugmentation may be more suitable than biostimulation in the following cases:

* treatment of high recalcitrant compounds

* treatment of contaminant present in relatively high or very low concentrations

* treatment of sites contaminated by very recent spillages

* treatment of environments where a particular physicochemical characteristic inhibits the activity of indigenous microbiota.

Table 2 Possible strategies to improve the bioactivity of a microbial process

\begin{tabular}{|c|l|}
\hline & \multicolumn{1}{c|}{ Strategies } \\
\hline Chemical & $\begin{array}{l}\text { Addition of surfactants } \\
\text { Promotion of cometabolism } \\
\text { Supply of co-substrates } \\
\text { Induction of metabolism by chemical analogues }\end{array}$ \\
\hline Microbial & $\begin{array}{l}\text { Selective in-situ enrichment } \\
\text { Bioaugmentation with non indigenous degraders }\end{array}$ \\
\hline Environmental & $\begin{array}{l}\text { Alteration of environmental conditions (pH, moisture } \\
\text { etc.) }\end{array}$ \\
\hline
\end{tabular}

Several factors can, however, affect the success or failure of bioaugmentation (Edgehill et al., 1991). They are related to nature, and type of inoculated microbial species and/or its specific size. Phenomena occurring at the treated contaminated site such as:

* adsorption on solid particles,

* diffusion constraints,

* competition effects by indigenous microorganisms,

* inhibition by toxic compounds may negatively influence a successful application of bioaugmentation (Trevors et al., 1994).

Suitable strategies may be carried out to overcome chemical and environmental constraints (biostimulation). For example, delivery systems may be designed to provide nutrients (nitrogen and phosphorous) and/or electron acceptors to stimulate and maintain the activity of microbial degraders. Similarly, environmental conditions can be improved to get optimal values of $\mathrm{pH}$, moisture etc. for microbial degradation of the organic pollutant. Substances more amenable to biodegradation than the target contaminant can be added to soil to stimulate the microbial cometabolic transformation of the pollutants, otherwise notdegraded.

An alternative option is the use of vegetal organisms, usually higher plants, capable to remediate a contaminated soil (Siciliano and Germida, 1998). Plants may utilize different mechanisms to efficiently remove, for example, hydrocarbons from a polluted soil. Evapotranspiration, effective only toward volatile hydrocarbons, uptake and breakdown of pollutants into smaller products, as well as accumulation in the root zone and/or translocation to aerial parts are the main mechanisms of a phytoremediation action. 
Table 3 Advantages and disadvantages of surfactants application

\begin{tabular}{|l|l|}
\hline Advantages & $\begin{array}{l}\text { Desorption of contaminants from the solid phase } \\
\text { Dispersion of the mass of the contaminant itself } \\
\text { Promotion of the partitioning of the contaminant into the aqueous } \\
\text { phase in the subsurface system }\end{array}$ \\
\hline Disadvantages & $\begin{array}{l}\text { Distribution of the surfactant in the contaminated medium (physical } \\
\text { disturbance) } \\
\text { Achievable in situ only for a near-surface distribution } \\
\text { Interference with both the degradation process and the soil properties } \\
\text { Toxicity }\end{array}$ \\
\hline
\end{tabular}

An interesting phenomenon is the synergic interaction between plants and microorganisms that specifically occurs in the rhizosphere. The beneficial, mutual effect of microbial and plant actions may result in a more efficient removal of pollutants from the contaminated soil (Siciliano and Germida, 1998).

\section{Degradation of organic pollutants by soil enzymes}

Several extracellular enzymes are efficient catalysts of organic pollutant transformation. The main enzymatic classes are oxidoreductases and hydrolases. Both these enzymes may explicate a degradative function and transform polymeric substances into partially degraded or oxidized products that can be easily uptaken by cells (Gianfreda and Rao, 2004). These latter in turn provide to their complete mineralization. For instance, partial oxidation of recalcitrant pollutants such as PAHs by extracellular oxidative enzymes give rise to products of increased polarity and water solubility and thus with a higher biodegradability (Meulenberg et al., 1997).

Extracellular enzymes with a potential in the degradation of pollutants are of both plant and microbial origins. Indeed, degradative enzymes released by plant roots in their surrounding environment may give an important contribution to the degradation occurring in the rhizosphere. These enzymes are usually wall-associated enzymes (ecto enzymes) and provide to partially transform substances in products more easily up-taken by plant roots or rhizosphere microorganisms.

Amounts of peroxidase, laccase and monophenoloxygenases capable of transforming even recalcitrant pollutants such as phenols, polychlorinated biphenyls (PCBs), polycyclic aromatic hydrocarbons (PAHs) and estrogenic chemicals were detected in the rizosphere of several plants (Caza et al., 1999, Chroma et al. 2002, Gramms et al. 1999, Shi et al. 2002). The plant nature of these enzymes was confirmed by experiments performed with sterile soils. In some cases the presence of xenobiotics was, however, toxic to both the plant and its enzymatic production.

The most abundant producers of oxidoreductases for the degradation of pollutants are microorganisms and mainly fungi such as wood-degrading basidiomycetes, terricolous basidiomycetes, ectomycorrizal fungi, soil-borne microfungi, and actinomycetes.

Several researchers have focused their attention on fungi as bioremediating agents (Reddy, 1995; Cameron and Aust, 1999; Cameron et al., 2000; Pointing, 2001). Most fungi are robust organisms and may tolerate higher concentrations of pollutants than bacteria. In particular, white-rot fungi appear unique and attractive organisms for the bioremediation of polluted sites for several 
reasons (Reddy, 1995, Bumpus, 1993) such as their ubiquity in natural environments; their unique capability of producing the lignin-degrading enzyme system (LDS), a very powerful extracellular oxidative enzymatic system. LSD is a combination of the two glycosylated heme-containing peroxidases, lignin peroxidase (LiP) and Mndependent peroxidase (MnP), and of a copper-containing phenoloxidase, laccase (L), with broad substrate specificity and capable to oxidize several environmental pollutants (Reddy, 1995; Pointing, 2001). The three enzymes are mainly of constitutive nature and may be usually expressed under nutrient-deficient conditions that are prevalently encountered in most contaminated soils (Cameron et al, 2000). Moreover, white-rot fungi, being filamentous fungi, can reach the soil pollutants by hyphal extension and extend in the soil with growth.

The LSD system along with an $\mathrm{H}_{2} \mathrm{O}_{2}-$ generating system and cellulolytic and hemicellulolytic enzymes, may act synergistically during the decay of wood. LiP and MnPs action is $\mathrm{H}_{2} \mathrm{O}_{2}$. The first oxidizes the removal of an electron from a variety of lignin-related aromatic structures producing aryl cation radicals. The second catalyzes the oxidation of $\mathrm{Mn}$ (II) to $\mathrm{Mn}$ (III), which in turn oxidizes several phenolic compounds (Reddy and D'Souza, 1994, Higuchi, 1993, Wariishi et al., 1992). By contrast, laccase requires oxygen to transform phenolic substrates to phenoxy radicals (Gianfreda et al., 1999). Laccases can also oxidize non-phenolic aromatics when mediators such as 2,2'-azino-bis(3-ethylbenzthiazoline-6-sulfonic acid, (ABTS), 3hydroxyanthranilate, 1-hydroxybenztriazole (HTB) and others are present in the reaction mixture (Bourbonnais et al., 1997; Pointing et al., 2000).

The LiPs are particularly attractive as pollutant degraders. They are relatively non-specific, have a very high oxidationreduction potential, and can potentially oxidize xenobiotics usually difficult to be affected by other peroxidases (Reddy and D'Souza, 1994, Higuchi, 1993).

A variety of pollutants biodegraded by fungi in which the lignin-degrading system (LDS), or some of its enzymatic constituents, played the primary role in the process is summarized in Table 4. The efficiency of pollutant biodegradation depended on both the type of pollutant and the fungus involved in the process. Very recalcitrant and toxic compounds like PAHs or PCBs with a high number of $\mathrm{Cl}$ substitutions were efficiently mineralized by various types of white-rot fungi (Table 4). In some cases, besides LDSs, the involvement of other enzymes was recognized to be crucial to the mineralization process. For instance, some pollutants such as 2,4,6-trinitrotoluene (TNT), the explosive of major environmental concern, or carbon tetrachloride (CCl4) were significantly transformed by cellobiose dehydrogenase (Cameron and Aust, 1999; Cameron et al., 2000). 
Table 4. Biodegradation of pollutants by fungi and their extracellular oxidases

\begin{tabular}{|c|c|c|c|}
\hline Pollutant & Enzyme & Source & Reference \\
\hline Azo dyes & Laccase & Pycnoporus sanguineis & Pointing and Vrijmoed. 2000 \\
\hline $\begin{array}{l}\text { Biopolymers (kraft, } \\
\text { lignin) }\end{array}$ & $\mathrm{LiP}, \mathrm{MnP}$ & White-rot fungi & $\begin{array}{l}\text { Cameron et al., 2000; Pointing, } \\
\text { 2001; Reddy, 1995; }\end{array}$ \\
\hline Bleach plant effluents & Laccase & P. sanguineis & $\begin{array}{l}\text { Archibald et al., 1990, Limura } \\
\text { et al., } 1996\end{array}$ \\
\hline $\mathrm{CCl}_{4}, \mathrm{CHCl}_{3}$ & $\begin{array}{l}\mathrm{LiP} \\
\mathrm{MnP},\end{array}$ & P. chrysosporium & Cameron and Aust, 1999 \\
\hline PAHs & $\begin{array}{l}\text { LDSs, } \\
\text { Laccase }\end{array}$ & $\begin{array}{l}\text { P. chrysosporium, } \\
\text { Trametes versicolor }\end{array}$ & $\begin{array}{l}\text { Bumpus 1989, Bogan and } \\
\text { Lamar } 1996\end{array}$ \\
\hline PCBs & $\mathrm{LiP}, \mathrm{MnP}$ & $\begin{array}{l}\text { Coriolopsis polyzona, } \\
\text { Pleurotus ostreatus, } T \text {. } \\
\text { versicolor }\end{array}$ & $\begin{array}{l}\text { Zeddel et al., 1993, Novotny et } \\
\text { al., } 1997\end{array}$ \\
\hline PCP & LDSs & $\begin{array}{l}\text { P. chrysosporium, } T \text {. } \\
\text { versicolor, Inonatus } \\
\text { dryophilus }\end{array}$ & $\begin{array}{l}\text { Alleman et al., } 1995 \\
\text { Lin et al., } 1990\end{array}$ \\
\hline TNT, RDX & $\begin{array}{l}\mathrm{LiP} \\
\mathrm{MnP}\end{array}$ & White-rot fungi & $\begin{array}{l}\text { Cameron, 2000; Bumpus and } \\
\text { Tatarko, } 1994\end{array}$ \\
\hline
\end{tabular}

Most of the studies were performed with Phanaerochaete chrysosporium. As reviewed by Cameron et al. (2000) and Rubilar et al, (2006), several enzymes and highly reactive, non specific, redox mediators produced by the fungus render it capable of efficiently degrading several toxic compounds. That extracellular oxidoreductases were involved in the biodegradation of several pollutants by fungi was conclusively demonstrated by studies performed with purified enzymes. For example, white-rot fungi and bacteria are capable to transform TNT and form dinitrotoluenes (DNTs) (e.g. 2-amino-4,6dinitrotoluene, 2,4-diamino-6-nitrotoluene, 2,6-diamino-4-nitrotoluene, and 4-amino-2,6dinitrotoluene) (Donnelly et al., 1997).

Another example of the catalytic capability of fungal oxidative enzymes is with azo dyes. Azo dyes are synthetic chemicals, widely used in the industry, with a high toxicity towards living organisms. The total production of synthetic dyes in the world is estimated to be around 800.000 t per year. Many different commercial dyes have a high stability to light, temperature, detergent and microbial attack, which make them resistant to biodegradation. Fungi have been proved to be able to decolorize azo dyes. The mechanism of colour removal involves LiP,
Mn-peroxidase and laccase enzymes. For example, Bhunia et al. (2001) in studies performed with peroxidase and a large variety of azodyes demonstrated that: the enzyme showed a different reactivity towards several industrially important azo and non azo (crystal violet) dyes and a consistent deactivation of the enzyme was the most limiting factor. Further studies performed by Torres et al. (2003) identified the possible mechanism involved in the detoxification of phenolic azodyes performed by peroxidases and laccases from different origins. In particular the mechanism involves three steps and leads to the detoxification of azo dyes since no aromatic amines are formed.

Another group of microbial enzymes involved in the pollutant transformation is the class of hydrolases. Extra or ecto cellular enzymes including proteases, carbohy dratases (e.g. cellulases, amylases, xylanases, etc.), esterases, phosphatases and phytases are produced by several bacteria and fungi, being physiologically necessary to their metabolism. Proteases and carbohydratases catalyze the break down of large molecules, such as proteins and carbohydrates, into smaller products more easily absorbed by cells. Others, like phosphatases and phytases, contribute to the nutrition of 
plants and microbes by hydrolysis of organic P compounds into inorganic $\mathrm{P}$, the only form of phosphorous available to plants and microbial cells.

Hydrolases have low substrate specificity and as such may contribute consistently to the bioremediation of several pollutants including insoluble wastes.

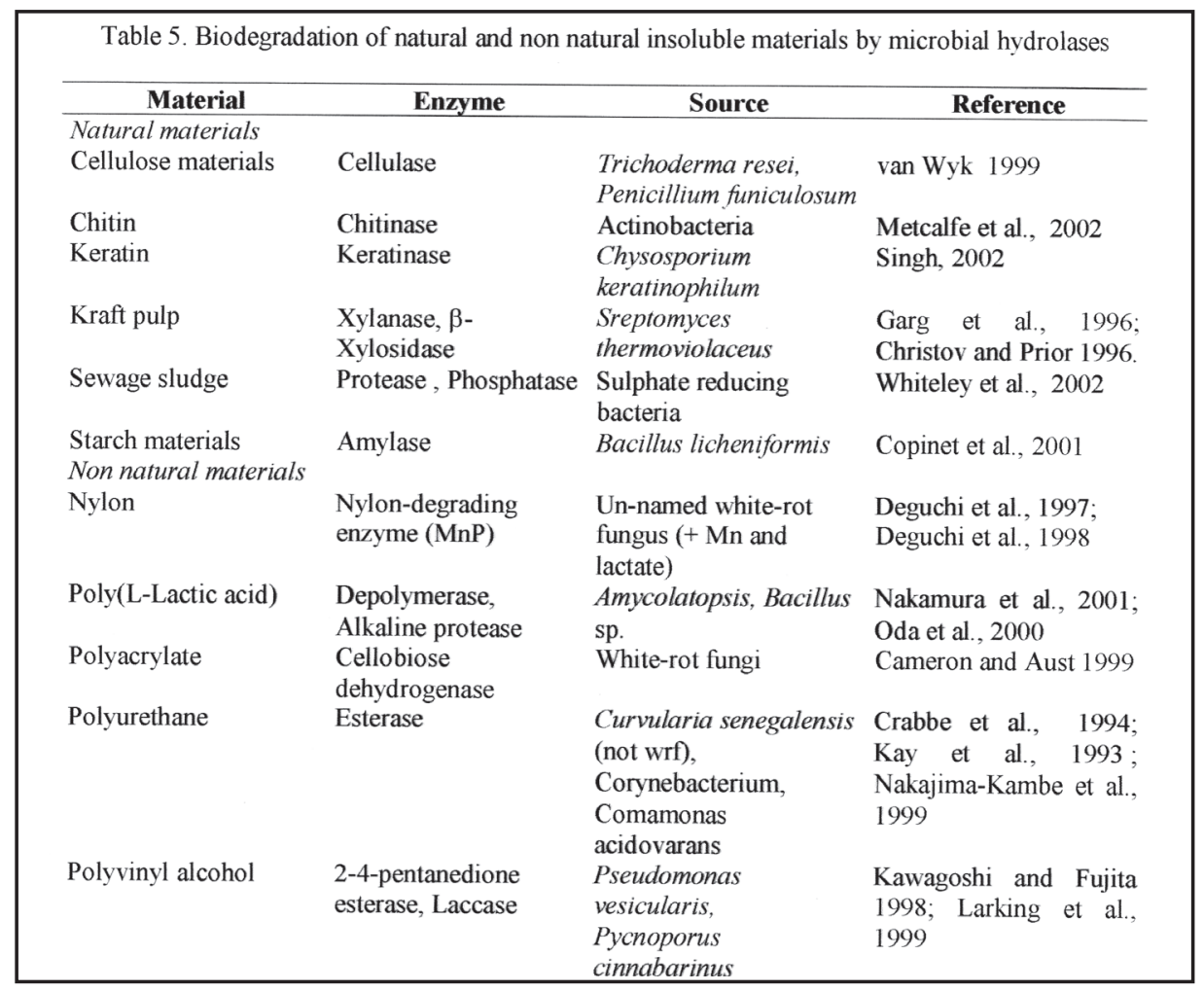

A list of microbial hydrolases involved in the transformation of natural and non natural insoluble compounds, their preferential substrates and main sources is reported in Table 5. Keratinic wastes deriving from animal breeding, processing and handling, as well as used paper products discarded by human population, may contribute largely to enrich the environment with solid wastes. Extracellular proteases (Singh 2002) as well as cellulases (Wyk 1999), were proven to be very effective in the transformation of keratin substrates and paper materials of different origin (e.g. foolscap, filter, office, and newspaper and microcrystalline cellulose, $\mathrm{MCC}$ ) respectively.

A class of modern pollutants of a great environmental concern are plastics, i.e. synthetic, man-made materials widely used in modern society for several purposes. They include polyurethanes, polyacrylates, polylactides, nylon, starch polymers, and mixed composites of different starting materials. Most of these materials are highly recalcitrant and when discarded in the environment, their persistence and high visibility may highly contribute to landfills with severe problems of environmental pollution. In spite of their intrinsic low vulnerability to microbial transformation, most of these materials have been found to be biodegraded by soil microorganisms (Table 5). Due to the molecular complexity of these materials, different microbial mechanisms have been invoked to explain the capability of bacteria and fungi to efficiently degrade them (Howard, 2002 and references therein). 
In several cases, the primary effectors of plastic biodegradation are extracellular enzymes, like esterases and depolymerases (Nakajima-Kambe et al., 1999, Langsford, 1987). Nakamura et al. (2001) showed that Amycolatopsis sp. strains K104-1 were able to depolymerise the polylactic acid (PLA) to its monomer lactic acid by the production of unique extracellular PLA-depolymerase.

$P$. chrysosporium and $\mathrm{T}$. versicolor under ligninolytic culture conditions were able to significantly degrade nylon, a linear polymer with amide bonds similar to those of proteins but not susceptible to the action of proteases (Deguchi et al. 1997). The responsible of this activity was a nylondegrading enzyme in the extracellular medium of a ligninolytic culture of the white rot fungus strain IZU-154 (Deguchi etal. 1998).

Several of the above pollutants transformations are started by an extracellular enzyme/s but require the presence of the whole cell and its metabolic pathways to be completed. In some cases the use of whole cells in the bioremediation of polluted sites may present some constraints that can be overcome by the use of cell-free enzymes isolated from their originating cells. The properties, potentialities and restrictions of isolated enzymes in the transformation and detoxification of organic pollutants have been recently examined by Gianfreda and Bollag, (2002) and Gianfreda and Rao (2004). The potential applications of several enzymes in the solid, liquid, and hazardous waste treatment were previously reviewed by Nannipieri and Bollag (1991), Karam and Nicell (1997) and Nicell (2001).

Indeed, cell-free enzymes have a unique substrate-specificity and catalytic power; they are capable to act in the presence of many toxic, even recalcitrant, substances, and/or under a wide range of environmental conditions, often unfavourable to active microbial cells (i.e. relatively wide temperature, $\mathrm{pH}$ and salinity ranges, high and low concentrations of contaminants); Enzymes are not sensitive or susceptible to the presence of predators, inhibitors of microbial metabolism, and drastic changes in contaminant concentrations.

Pesticides of different chemical nature, very recalcitrant compounds like asphaltenes and PCBs, polychlorophenols, PAHs and others toxic pollutants have been successfully transformed by oxidoreductases and hydrolases isolated by fungal, bacterial and plant cells (Table 6).

Notwithstanding, the use of isolated enzymes as tools in the detoxifications of polluted sites may be hampered by several drawbacks.

The studies by Bollag and co-workers (for a detailed list see reported references in Gianfreda et al., 1999) and Gianfreda and coworkers (Gianfreda et al., 1998 ; Filazzola et al., 1998, 1999 ; Sannino et al.,1999; Rao et al., 2003,) have demonstrated that laccases from different fungal origins were capable of removing a large variety of phenols and the efficiency was strictly dependent on the chemical structure of the phenol, the type and the number of substituents on the aromatic ring (Table 6).

Another interesting application of cellfree enzymes is the use of the so-called nitrile-degrading enzymes capable of degrading nitrile compounds (Banerjee et al. 2002). Nitrile compounds are widespread in the environment. They comprise some of plant origins, such as cyanoglycosides, cyanolipids, ricinine, phenylacetonitrile, etc. Nitrile compounds are also extensively used in chemical industries to produce a variety of polymers and other chemicals. Other different nitrile compounds are used as feedstock, solvents, extractants, pharmaceuticals, drug intermediates (chiral synthons), pesticides (dichlobenil, bromoxynil, ioxynil, buctril), or as intermediates in the organic synthesis of a variety of different compounds (e.g. amines, amides, amidines, carboxylic acids, esters, aldehydes, ketones and heterocyclics) . 


\begin{tabular}{|c|c|c|c|}
\hline \multicolumn{4}{|c|}{ Table 6. Biodegradation of pollutants by cell-free enzymes } \\
\hline Pollutant & Enzymes & Source & Ref. \\
\hline $\begin{array}{l}\text { Anthracene, } \\
\text { Pyrene }\end{array}$ & & Nocardia forwardii & Guenther et al., 1998 \\
\hline Asphaltenes & Chloroperoxidase & Cladariomyces fumago & $\begin{array}{l}\text { Fedorak et al., 1993; Mogollon } \\
\text { et al., } 1998\end{array}$ \\
\hline $\begin{array}{l}\text { Carbofuran, } \\
\text { Carbaryl }\end{array}$ & $\begin{array}{l}\text { Carbamate } \\
\text { hydrolase }\end{array}$ & $\begin{array}{l}\text { Achromobacter sp. } \\
\text { Pseudomonas sp. }\end{array}$ & $\begin{array}{l}\text { Derbyshire et al., 1987; Mulbry } \\
\text { and Eaton } 1991\end{array}$ \\
\hline Cyanides & $\begin{array}{l}\text { Cyanidase, Cyanide } \\
\text { hydratase }\end{array}$ & $\begin{array}{l}\text { Alcaligenes denitrificans, } \\
\text { Several fungi }\end{array}$ & $\begin{array}{l}\text { Basheer et al., 1992; } \\
\text { Basheer et al., 1993; Barclay et } \\
\text { al., } 1998 \text {; Lynch, } 2002\end{array}$ \\
\hline $\begin{array}{l}\text { Estrogenic } \\
\text { chemicals }\end{array}$ & MnP, Laccase & Trametes versicolor & Tsutsumi et al, 2001 \\
\hline $\begin{array}{l}\text { Nitrile } \\
\text { compounds }\end{array}$ & $\begin{array}{l}\text { Nitrilase, nitrile } \\
\text { hydratase, amidase }\end{array}$ & $\begin{array}{l}\text { Nocardia, sp., } \\
\text { Rhodococcus } \mathrm{sp} \text {. } \\
\text { Fusarium solani }\end{array}$ & Banerjee et al., 2002 \\
\hline $\begin{array}{l}\text { PCP, DDT, } \\
\text { PCBs, Lindane }\end{array}$ & $\begin{array}{l}\text { Dehalogenases, } \\
\text { Laccase }\end{array}$ & Several microorganisms & Beaudette et al., 2000 \\
\hline Phenols, PAH & $\begin{array}{l}\text { MnP, LiP, Laccase, } \\
\text { Chloroperoxidases, } \\
\text { Peroxidase }\end{array}$ & White-rot fungi & $\begin{array}{l}\text { Nicell, 2001, Gianfreda et al., } \\
\text { 1998; Filazzola et al., 1999; } \\
\text { Bollag et al., } 1988\end{array}$ \\
\hline $\begin{array}{l}\text { Pyrethroids, } \\
\text { Parathion, } \\
\text { Diazinon }\end{array}$ & & $\begin{array}{lr}\text { Agrobacterium, } & \\
\text { Pseudomonas } & \mathrm{sp} . \\
\text { Flavobacterium } & \mathrm{sp} .\end{array}$ & $\begin{array}{l}\text { Coppella et al., 1990; Mulbry, } \\
\text { 1998; } \\
\text { Sutherland et al., } 2002\end{array}$ \\
\hline & & $\begin{array}{l}\text { Nocardia } \mathrm{sp} ; \text { Bacillus } \\
\text { cereus }\end{array}$ & \\
\hline
\end{tabular}

Most nitriles are however highly toxic, mutagenic and carcinogenic in nature (Pollak et al., 1991). If present in the environment at high concentrations they may cause severe diseases in humans. Consequently, efforts have been made to control their release in the environment, and/ or to remove them from it. As reviewed by Banerjee et al. (2002), several bacteria and some fungi posses enzymatic capabilities to metabolize several natural and synthetic nitriles. Based on their substrate specificity, nitrile-converting enzymes consist of three major categories: nitrilases, nitrile hydratases and amidases.

The enzymes may be of both constitutive and inducible nature and present some common features such as optimum activity at alkaline or sub-alkaline $\mathrm{pH}$ and a good stability in a large range of temperatures. One of their most common uses is in the synthesis of several pharmaceuticals and useful chemicals (Banerjee et al. 2002).

These enzymes are, however, versatile catalysts and could be potentially usable in several fields including bioremediation.
Wyatt and Knowles (1991) reported that mixed cultures of bacteria containing different nitrile hydrolyzing enzymes (including nitrile hydratases, nitrilase and amidase) biodegraded effluents from acrylonitrile manufacturing industries.

Another group of useful enzymes in the detoxification of toxic, hazardous compounds is the one involved in the transformation of cyanides. These are common contaminants of brown field sites, especially old gasworks. Large pollution of water by cyanide-wastes, and the consequent severe damages to natural fauna, may also occur. Fungi and bacteria may effectively catabolize cyanides by means of cyanide-catabolizing enzymes that include formamide hydrolase and rhodanese. Lynch (2002) has reported that the introduction of a selected strain of Trichoderma in the rhizosphere soil rapidly catabolized phytotoxic concentrations $(10 \mathrm{mM})$ of cyanide through the action of the two enzymes. Thus, the application of these enzymes for the remediation of cyanidepolluted sites can be envisaged. 

Extracellular enzymes as agents for the
remediation of polluted soils

If isolated enzymes are the detoxifying agents, several requirements are mandatory: a suitable enzyme and its best source must be identified using selective screening by means of conventional microbiological approaches; the enzyme-producing microorganism must be cultured to increase the enzyme yield, or to extract the enzyme for cell-free applications; the enzyme must be stable under the operational conditions (see above).

When pollutants transformation occurs in the polluted site, particularly soil, and extracellular enzymes are required to start the process, a general lower efficiency of the biological agent is usually observed. For instance, several investigations have demonstrated that white rot-fungi, and their extracellular oxidases, are less capable to transform pollutants of different nature when acting directly in soil (Reddy, 1995, Pointing, 2001; Rubilar et al., 2006 and references therein) compared to the results obtained in laboratory studies of submerged liquid cultures. When cell-free enzymes are then considered, very few examples are available on the use of isolated enzymes for the detoxification of pollutants in soil (Gianfreda and Bollag 2002; Nannipieri and Bollag, 1991).

In a natural environment such as soil, several drawbacks or disadvantages may hinder or diminish the catalytic potential of these enzymatic catalysts (Nannipieri and Bollag, 1991). The disadvantages of in situ application of extracellular, cell-associated or cell-free enzymes, may depend on both the pollutants and the enzymes.

Since in a polluted site, combinations of many organic (and inorganic) contaminants, rather than a single polluting substance are normally present, possible negative, or positive, synergistic effects on the enzyme efficiency may occur.

The catalytic effectiveness of laccase and peroxidase of removing several toxic compounds (i.e. Cl-Anilines, Cl-, Brphenols, naphthols, bentazon) has been extensively studied by Bollag and coworkers under laboratory conditions when acting in the presence of co-substrates or humic precursors (i.e. catechol, guaiacol, fulvic acid, syringic acid, protocatechuic acid, syringic acid, vanillic acid) (Gianfreda et al., 1999 and references therein). The nature of polymeric products as well as the possible mechanisms involved in the process was addressed. Increases and/or decreases of the pollutant transformation measured as either polymerization or mineralization of the target pollutant were detected.

It was also demonstrated that the 2,4dichlorophenol (2,4-DCP) decrease by laccases from different origins (i.e. Cerrena unicolor, Trametes villosa) was differently affected by the co-presence of one or two other chlorophenols such as 4-chlorophenol or 2,4,6 thriclorophenol (Bollag et al., 2003). In another study, enhancing or depressing effects of a laccase from Rhus vernicifera on catechol transformation were measured in binary, ternary, and quaternary aqueous phenolic mixtures of four phenols (catechol, methylcatechol, tyrosol and hydroxytytrosol) (Rao et al., 2003), simulating a typical wastewater deriving from an olive oil factory.

Differentiated effects on the enzyme activity were also observed by the presence of a polluting substance non-substrate of the enzyme. Investigations performed under laboratory conditions with acid phosphatase from sweet potato a typical, extra or ecto cellular enzyme, and pesticides such as carbaryl, atrazine, and glyphosate demonstrated that the activity of the enzyme was depressed by atrazine and carbaryl (40 and $34 \%$ of activity reduction, respectively), whereas no effects were measured with glyphosate (Sannino and Gianfreda, 2001).

As reported above, bioavailability is a key factor possibly affecting the pollutants transformation and in soil, it can be 
influenced by several properties such as the amount of organic matter, the thickness of silt and clay beds, the presence of dissolved organic matter, the soil aggregation and subsuperficial heterogeneity (Gianfreda and Nannipieri, 2001).

Adsorption and/or entrapment of pollutants on/into organic and inorganic soil colloids and in soil matrix further complicate the whole system, and can limit the amount of pollutant available to microbial cells and their extracellular enzymes. Their limiting effect can be greater toward isolated enzymes. Aging processes can also lead to a significant reduction of pollutants bioavailability, because of their sequestration from diffusion into sites within sorbing matrices or entry into nanopores, both not easily accessible to large molecules as enzymatic proteins (Alexander, 2000).

Disadvantages to the in situ application of extracellular, cell-associated or cell-free enzymes may also arise from the enzymes.

Enzymes may loose their activity upon pollutant transformation. In the experiments with phenols and laccase, the residual activity of the enzyme was measured after phenol transformation under standard conditions (Filazzola et al., 1999, Gianfreda et al. 1999; Gianfreda et al., 2002). The results indicated that the enzyme partially, or totally, lost its catalytic activity. The reduction of activity was quite dependent on the type of phenols, its transformation and the combination of the phenols in the mixture. Usually the higher the phenol concentration was, the more pronounced the loss of laccase activity was. The authors explained their results as due to the progressive entrapment and/or adsorption of active enzyme molecules within/on phenol polymeric aggregates as they formed (Filazzola et al., 1999, Gianfreda et al. 1999).

Enzymes may be deactivated by their substrates, by their reaction products or other compounds. In particular the use of peroxidase is strongly hindered by the deactivation of the enzyme by hydrogen peroxide. In their investigation with different compounds capable of contrasting the deactivation of a peroxidase Tonegawa et al., (2003) showed that a high increase of 2,4-DCP removal occurred in the presence of PEG or Triton X100.

Enzymes may decrease their activity in the presence of soil colloids. Investigations were performed to evaluate the effectiveness of laccases from different origins and toward 2,4-DCP removal in the presence of different inorganic, organic and organo-mineral soil colloids and whole soils with different organic matter contents. Results demonstrated that soil components and soils differently affected 2,4-DCP-laccase activity (Filazzola et al., 1999, Gianfreda et al. 1999).

As regards to isolated enzymes, a drawback that greatly hampers their practical application is the cost of enzymes isolation and purification. Given the best producer of the selected enzyme, the production of a purified enzyme requires long and expensive isolation and purification procedures. Furthermore, very low amounts of the purified protein are usually obtained thus rendering the whole process too costly for practical applications. Alternative inexpensive technologies, using for instance agricultural wastes as the carbon source, may be adopted to increase the growth of the enzyme-producing microorganisms and to significantly reduce the cost of enzyme production (van Beilen and Li, 2002). Even if the enzymes are available at very low costs, their use in soil as free proteins may be hindered by their short life in an inhospitable environment such soil (Gianfreda and Bollag, 1994, 2002; Nannipieri and Bollag, 1991).

An interesting, low-cost alternative to the use of purified enzymes can be the utilization of plant material loading enzymatic activities and proved to be effective in the detoxification of polluting substances. As it is the case of the results obtained in the investigations performed 
with minced horseradish roots (Dec and 1994; Roper et al., 1996) and olive husk, a by-product of olive oil production showing phenoloxidase activity (Greco et al., 1999; Toscano et al., 2003), used for the successful transformation of phenolic pollutants. Improvements in the production of isolated enzymes may also derive from molecular technologies. Production of animal and plant enzymes could be performed by means of genetically modified microorganisms or plants (OECD, 1998; Hood, 2002).

In conclusion, the widespread use of these catalysts for practical applications, mainly as agents for the decontamination of polluted systems (aquatic and terrestrial), is, however, still hampered by all the above drawbacks that can be summarized as: a) a) reduction of their catalytic efficiency after the catalytic action (loss of enzymatic activity or of catalyst amount); b) catalyst deactivation by interaction with formed polymeric products; c)low stability if applied in the environment (deactivating effects, influence of soil colloids) and d) requirement of large amounts of catalysts (in some cases).

However, the range of sophisticated modern molecular technologies now available has provided the researcher with an immensely enhanced choice of potential enzyme sources. In particular, an increasing knowledge of several aspects of the enzymology and molecular biology of the powerful extracellular oxidative system (LDS) of fungi is now available (Reddy, 1995; Pointing, 2001). These advancements should lead to the successful genetic engineering of white-rot fungi and their enzyme systems. Most advantageous bioremediation strategies for treating contaminated sites can thus possibly be planned and applied.

The engineering of microbes and enzymes may also help to improve bioremediation, particularly when the application on a large-scale of the selected biological catalyst is hampered by the low rate of pollutant degradation (Chen et al., 1999). As claimed by Chen and Mulchandani (1998), recent advantages in genetic and molecular techniques have offered new chances to modify microbes or enzymes to function as "designer biocatalysts" in which certain required qualities from different organisms are brought together in a single catalyst to perform specific bioremediation.

Enzymes immobilized on natural and synthetic supports of different nature and through different immobilization mechanisms have been often proposed as efficient catalytic tools to overcome several disadvantages linked to the use of free enzymes (Gianfreda and Bollag, 2002; Nannipieri and Bollag, 1991). Immobilized enzymes have usually a long-term and operational stability, being very stable toward physical, chemical, and biological denaturing agents.

Furthermore, they may be reused and recovered at the end of the process. While the use of immobilized enzymes is widely diffused in several applicative fields, including environmental applications (Nannipieri and Bollag, 1991; Karam and Nicell, 1997; Nicell, 2001; Duran et al., 2002), their large-scale application in the bioremediation of polluted soils is not reported, at least to our knowledge.

The potential of enzymes for bioremediation purposes can greatly increase by the use of microorganisms and their enzymes from extreme environments. Enzymes from both thermophilic and psycrophilic microorganisms usually display some unusual and particular features that may render them potential, powerful catalysts for the degradation of polluting chemicals (Gerday et al., 2000 and references therein, Haki and Rakshit, 2003). Thermophiles and psycrophiles have to adapt themselves to live and survive under extreme environmental conditions (Rothschild and Manicinelli, 2001). As a consequence, specialized enzymatic proteins, particularly stable to different 
denaturing agents, and with elevated catalytic activity, are produced.

The molecular, structural, kinetic and genetic properties of such enzymes have been in most cases elucidated. Cloning and expression of genomic related information in heterologous, fast-growing meshophiles, like E. coli, has allowed an increased, much less cheaper commercial production of thermophilic enzymes (Hough and Danson, 1999; Ikeda and Clark,. 1998; Bruins et al., 2001). An increasing knowledge of coldadapted enzymes properties is now being developing, as well (Gerday et al., 2000).

Many industrial applications have benefited from the use of these enzymes. More challenges and potential advantages may also be envisaged for their application in biotechnology including bioremediation (Gerday et al., 2000 and references therein, Haki and Rakshit, 2003).

\section{ACKNOWLEDGMENT.}

This work was carried out with the financial support of the "Ministero dell'Università e della Ricerca”, Italy. Programs of National Interest (PRIN 20032005) and the "European Commission", INCO-MED Program (Contract ICA3-CT2002-10033).

\section{REFERENCES}

ADRIANO D.C., BOLLAG J.-M., FRANKENBERGER W.T.JR, SIMS R.C. 1999. Biodegradation of Contaminated Soils Agronomy Monograph 37, American Society of Agronomy, Crop Science of America, Soil Science Society of America, 772 pp.

ALEXANDER M. 1985. Biodegradation of organic chemicals. Environ. Sci. Technol., 19:106-11.

ALEXANDER M.. 1994. Biodegradation and Bioremediation, Academic Press, San Diego, 139 pp.
ALEXANDER M. 2000. Aging, bioavailability, and overstimation of risk from environmental pollutants. Environ. Sci. Technol. 2000, 34, 4259-4265.

ALLEMAN B.C, LOAN B.E, AND GILBERTSON R.L. 1995. Degradation of pentachlorophenol by fixed films of whiterot-fungi in rotating tube bioreactors. Wat. Res. 1995, 29, 61-67.

ARCHIBALD F.S, PAICE M.G, AND JURASEK L.1990. Decolorization of kraft bleachery effluent chromophores by Coriolus (Trametes) versicolor. Enzyme Microb. Technol., 12, 846-853.

BANERJEE A, SHARMA R, AND BANERJEE U.C. 2002. The nitrile-degrading enzymes: current status and future prospects. Appl. Microbiol. Biotechnol., 60, 33-44.

BARCLAY M, HART, A, KNOWLES CJ, MEENSSEN J.C.L, AND TETT V.A. 1998. Biodegradation of metal cyanides by mixed and pure cultures of fungi. Enzyme Microb. Technol., 22, 223-231.

BASHEER S, KUT O.M., PRENOSIL J.E, AND BOURNE J.R. 1993. Development of an enzyme membrane reactor for treatment of cyanide-containing wastewaters from the food industry. Biotechnol. Bioeng. 39, 629-635.

BASHEER S, KUT O.M, PRENOSIL J.E, AND BOURNE J.R. 1992. Kinetics of enzymatic degradation of cyanide. Biotechnol. Bioeng. ,41, 465-473.

BEAUDETTE L.A, WARD O.P, PICKARD M.A, AND FEDORAK P.M. 2000. Low surfactant concentration increases fungal mineralization of a polychlorinated biphenyl congener but has no effect on overall metabolism. Lett. Appl. Microbiol., 30, 155160.

BLACKBURN J.W., HAFKER W.R.,1993. The impact of biochemistry, bioavailability and bioactivity on the selection of bioremediation techniques. Trends in Biotech., 11: 328-333.

BOGAN B.W, AND LAMAR R.T. 1996. Polycyclic aromatic hydrocarbon-degrading capabilities of Phanerochaete laevis HHB1625 and its extracellular ligninolytic enzymes. Appl. Environ. Microbiol., 62, 1597-1603. 
BOLLAG J-M., LIU S.-Y. 1990. Biological transformation processes of pesticides. In H.H. Cheng (ed.) Pesticides in the environment: process, impact and modelling. Soil Science Society of America, Madison, Wisconsin, pp.169-185.

BOLLAG J-M,, CHU R,, RAO M.A, AND GIANFREDA L. 2003. Enzymatic oxidative transformation of chlorophenol mixtures. J. Environ. Qual., 32, 62-71.

BOLLAG J-M, SHUTTLEWORTH K.L, AND ANDERSON D.H. 1988. Laccase-mediated detoxification of phenolic compounds. Appl. Environ. Microbiol. 54, 3086-3091.

BOLLAG J-M. AND BOLLAG W.B. 1995. Soil Contamination and the Feasibility of Biological Remediation. Bioremediation: Science and Applications., pp 1-12.

BOOPATHY R. 2000. Factors limiting bioremediation technologies. Biores. Technol., 74, 63-67.

BOURBONNAIS R, PAICE M.G, FREIERMUTH B, BODIE E, AND BORNEMAN S. 1997. Reactivities of various mediators and laccases with kraft pulp and lignin model compounds. Appl. Environ. Microbiol., 63, 4627-4632.

BOUWER E.J., ZEHNDER A.J.B.,. 1993. Bioremediation of organic compounds putting microbial metabolism to work. Trends in Biotech.,11: 360-367.

BRUINS M.E, JANSSEN A.E, AND BOOM R.M. 2001. Thermozymes and their applications: a review of recent literature and patents. Appl. Biochem. Biotechnol., 90,155-186.

BUMPUS J.A, AND TATARKO M. 1994. Biodegradation of 2,4,6-trinitrotoluene by Phanerochaete chrysosporium: identification of initial degradation products and the discovery of a TNT-metabolite that inhibits lignin peroxidase. Curr. Microbiol., 28, 185-190.

BUMPUS J.A. 1998. Biodegradation of polycyclic aromatic hydrocarbons by Phanerochaete chrysosporium. Appl. Environ. Microbiol., 55, 154-158.

BUMPUS J.A. 1993. White-rot fungi and their potential use in soil bioremediation processes. In: J.M Bollag and G. Stotzky (Eds.) Soil Biochemistry, Marcel Dekker, New York, 65-100.

BHUNIA A, DURANI S, AND WANGIKAR P. P. 2001 Horseradish peroxidase catalyzed degradation of industrially important dyes. Biotechnol. Bioeng., 72, 5627.
BURTON, S.G. 2001. Development of bioreactors for application of biocatalysis in biotransformation and bioremediation. Pure Appl. Chem.. 73, 77-83.

CAMERON M.D, AND AUST S.D. 1999. Degradation of chemicals by reactive radicals produced by cellobiose dehydrogenase from Phanerochaete chrysosporium. Arch. Biochem. Biophys., 367, 115-121.

CAMERON M.D, TIMOFEEVSKI S, AND AUST S.D. 2000. Enzymology of Phanerochaete chrysosporium with respect to the degradation of recalcitrant compounds and xenobiotics. Appl. Microbiol. Biotechnol., 54, 751-758.

CERNIGLIA, C.E. 1992. Biodegradation of polycyclic aromatic hydrocarbons. Biodegradation., 3: 351-368.

CHEN W, AND MULCHANDANI A. 1998. The use of live biocatalysts for pesticide detoxification. Trend. Biotechnol., 161, 71-76.

CHRISTOV L.P, AND PRIOR B.A. 1996. Repeated treatments with Aureobasidium pullulans hemicellulases and alkali enhance biobleaching of sulphite pulps. Enzyme Microb. Biotechnol., 18, 244-250.

CHROMA L, MACKOVA M, KUCEROVA P, IN DER WIESCHE C, BURKHARD J, AND MACEK T. 2002. Enzymes in plant metabolism of PCBs and Ps. Acta Biotechnol., 22, 35-41.

COPINET A, BLIARD C, ONTENIENTE J.P, AND COUTURIER Y. 2001. Enzymatic degradation and deacetylation of native and acetylated strach-based extruded blends. Polym. Degrad. Stabil., 71, 203-212.

COPPELLA SJ, CRUZ ND, PAYNE GF, POGELL BM, SPEEDIE MK, KARNS JS, SYBERT EM, AND CONNOR MA. 1990. Genetic engineering approach to toxic waste management case study for organophosphate waste treatment. Biotechnol. Progr., 6, 76-81.

CRABBE J.R, CAMPBELL J.R, THOMPSON L, WALZ S.L, AND SCHULTZ W.W. 1994. Biodegradation of a colloidal ester-based polyurethane by soil fungi. Int. Biodeter. Biodegr., 33, 103-113.

DEC J, AND BOLLAG J-M. 1994. Use of plant material for the decontamination of water polluted with phenols. Biotechnol. Bioeng., 44, 1132-1139. 
DEGUCHI T, KAKEZAWA M, AND NISHIDA T. 1997. Nylon degradation by lignindegrading fungi. Appl. Environ. Microbiol.,, 63, 329-331.

DEGUCHI T, KITAOKA Y, KAKEZAWA M, AND NISHIDA T.1998. Purification and characterization of a nylon-degrading enzyme. Appl. Environ. Microbiol., 64, 1366-1371

DERBYSHIRE, M.K., KARNS, J.S., KEARNEY, P.C., AND NELSON, J.O. 1987, Purification and characterization of an Nmethylcarbamate pesticide hydrolyzing enzyme. J. Agr. Food. Chem., 35, 871-877.

DONNELLY K.C, CHEN J.C, HUEBNER H.J, BROWN KW, AUTENRIETH R.L, AND BONNER J.S. 1997. Utility of four strains of white-rot fungi for the detoxification of 2,4,6-trinitrotoluene in liquid culture. Environ. Toxicol. Chem.,16, 1105-1110.

DURÁN N, ROSA MA, D'ANNIBALE A, AND GIANFREDA L.2002. Applications of laccases and tyrosinases (phenoloxidases) immobilized on different supports: a review. Enzyme Microbial. Technol., 31, 907-931.

EDGEHILL R.U. 1999. Bioremediation by Inoculation with Microorganisms. In: Biodegradation of Contaminated Soils (Adriano D.C., Bollag J.-M., Frankenberger W.T.Jr, Sims R.C., Eds) Agronomy Monograph 37, American.

EDGEHILL R.U., KELLEY B.C., AND RHODES S.H.1991. Bioremediation of contaminated sites. Chem. Eng. Aust., 16:8-10.

FEDORAK P.M, SEMPLE KM, VAZQUEZDUHALT R, AND WESTLAKE D.W.S. 1993. Chloroperoxidase-mediated modifications of petroporphyrins and asphaltenes. Enz. Microb. Technol., 429-437.

FETZNER S. AND LINGENS F.1994. Bacterial dehalogenases: biochemistry, genetics, and biotechnological applications. Microbiological Reviews, 58:641-685.

FILAZZOLA M.T, SANNINO F, AND GIANFREDA L. 1998. The influence of biological agents on the behaviour of pollutants in soil. Fres. Environ. Bull., 7, 484489.

FILAZZOLA, M.T, SANNINO F, RAO, M.A, AND GIANFREDA L. 1999. Effect of various pollutants and soil-like constituents on laccase from Cerrena unicolor. J. Environ. Qual., 28,1929-1938.
GARG, A.P, McGARTHY A.J, AND ROBERTS, J.C.1996. Biobleaching effect for Streptomyces thermoviolaceus xylanase preparations on birchwood kraft pulp. Enzyme Microbial. Biotechnol., 18, 261-267.

GERDAY C, AITTALEB M, BENTAHIR M, CHESSA J-P, CLAVERIE P, COLLINS T, D'AMICO S, DUMONT J, GARSOUX G, GEORLETTE D, HOYOUX A, LONHIENNE T, MEUWIS M-A, AND FELLER G. 2000. Cold-adapted enzymes: from fundamentals to biotechnology. Trends Biotechnol., 18, 103-107.

GEVAO B., SEMPLE K.T., AND JONES K.C.2000. Bound pesticide residues in soils: a review. Environ. Poll., 108, 3-12.

GIANFREDA L, AND BOLLAG J-M. 1994. Effect of soils on the behaviour of immobilized enzymes. Soil Sci. Soc. Am. J., 58, 1672-1681.

GIANFREDA L, AND BOLLAG J-M. 1996. Influence of natural and anthropogenic factors on enzyme activity in soil. In: G Stotzky, and J-M Bollag (Eds.) Soil Biochemistry vol. 9, Marcel Dekker, New York,123-194.

GIANFREDA L, AND BOLLAG J-M. 2002. Isolated enzymes for the transformation and detoxification of organic pollutants. pp. 491538. In: RG Burns and R Dick (Eds.) Enzymes in the Environment: Activity, Ecology and Applications Marcel Dekker, NY,

GIANFREDA L, AND NANNIPIERI P. 2001. Basic principles, agents and feasibility of bioremediation of soil polluted by organic compounds. Minerva Biotecnol. 13, 5-12.

GIANFREDA L. AND RAO M.A. 2004. Potential of extra cellular enzymes in remediation of polluted soils: a review. Enz. Microb. Technol., 35, 339-354.

GIANFREDA L, RAO M.A, SANNINO F, SACCOMANDI F, AND VIOLANTE A. 2002. Enzymes in soil: Properties, behaviour and potential applications. In: A Violante, P.M Huang, J-M Bollag, L Gianfreda (Eds.) Soil Mineral-Organic Matter-Microorganism Interactions and Ecosystem Health Development in Soil Science vol. 28B, Elsevier, Amsterdam.,301-328.

GIANFREDA L, SANNINO F, FILAZZOLA MT, AND LEONOWICZ A. 1998. Catalytic behavior and detoxifying ability of a laccase from the fungal strain Cerrena unicolor. J. Molec. Catal. B: Enzymatic, 14, 13-23. 
GIANFREDA L, XU F, AND BOLLAG J-M. 1999. Laccases: A useful group of oxidoreductive enzymes. Bioremediation J., 3, 1-25.

GRAMMS G, VOIGT KD, AND KIRSCHE B. 1998. Oxidoreductase enzymes liberated by plant roots and their effects on soil humic material. Chemosphere,38,1481-1494.

GRECO G.J.R, TOSCANO G, CIUFFI M, GIANFREDA L, AND SANNINO F. 1999. Dephenolisation of olive mill waste-waters by olive husk. Wat. Res.,33, 3046-3050.

GUENTHER T, SACK U, HOFRICHTER M, AND LAETZ M. 1998. Oxidation of PAH and PAH-derivatives by fungal and plant oxidoreductases. J. Basic. Microbiol., 38, 113-122.

HAKI GD, AND RAKSHIT SK. 2003. Developments in industrially important thermostable enzymes: a review. Biores. Technol., 89,17-34.

HAMER G.1993. Bioremediation:a response to gross environmental abuse. Trends in Biotech., 11,317-319.

HARAYAMA S. 1997. Polyciclic aromatic hydrocarbon bioremediation design. Curr. Op. Biotechnol., 8,268-273.

HARVEY PJ, XIANG M, AND PALMER JM. 2002. Extracellular enzymes in the rhizosphere. Proc. Inter-Cost Workshop on Soil-microbe-root interactions: maximising phytoremediation/bioremediation 2002, Grainau, Germany, 23-25..

HIGUCHI T.1993. Biodegradation mechanism of lignin by white-rot basidiomycetes. Biotechnol. 30, 1-8.

HOOD EE. 2002. From green plants to industrial enzymes. Enzyme Microb. Technol., 30, 279-283.

HOUGH D, AND DANSON M. 2002. Extremozymes. Curr. Opin. Chem. Biol., 3, 39-46

HOWARD G.T. 2002. Biodegradation of polyurethane: a review. Intern. Biodeter. Biodegrad., 49, 245-252.

IKEDA M, AND CLARK D. 1988. Molecular cloning of extremely thermostable esterase gene from hyperthermophilic archaeon Pyrococcus furiosus in Escherichia coli. Biotechnol. Bioeng.,57, 624-629.

IWAMOTO T, AND NASU, M. 2001. Current bioremediation practice and perspective. J. Biosci. Bioeng., 92, 1-8.
KARAM J, AND NICELL J.A. 1997. Potential application of enzymes in waste treatment. J. Chem. Tech. Biotechnol., 69, 141-153.

KAWAGOSHI Y, AND FUJITA M. 1999. Purification and properties of the polyvinyl alcohol-degrading enzyme 2,4-pentanedione hydrolase obtained from Pseudomonas vesicularis var. povalolyticus. World J. Microbiol. Biotechnol., 14, 95-100.

KAY M.J, MCCABE R.W, AND MORTON L.H.J. 1993. Chemical and physical changes occurring in polyester polyurethane during biodegradation. Inter. Biodet. Biodegrad.,31, 209-225.

KÖGEL-KNABNER, TOTSCHE K.U., AND RABER B. 2000. Desorption of polycyclic aromatic hydrocarbons from soil in the presence of dissolved organic matter: Effect of solution composition and aging. J. Environ. Qual., 29, 906-916.

KORDA A., SANTAS P. TENENTE A., SANTAS R.1997. Petroleum hydrocarbon bioremediation: sampling and analytical techniques, in situ treatments and commercial microorganisms currently used. Appl. Microbiol Biotechnol.,48, 677-686.

LANGSFORD M.L, GILKES N.R, SING S, MOSER B, MILLER J.R..WARREN R.A.J, AND KILBURN D.G.1987. Glycosylation of bacterial cellulases prevents proteolytic cleavage between functional domains. FEBS Letters, 225, $163-167$.

LARKING D.M, CRAWFORD R.L, CHRISTIE G.B.Y, AND LONERGAN G.T. 1999. Enhanced degradation of polyvinyl alcohol by Pycnoporus cinnabarinus after pretreament with Fenton's reagent. Appl. Environ. Microbiol., 65, 1798-1800.

LIMURA Y, HARTIKAINEN P, AND TATSUMI K.1996. Dechlorination of tetrachloroguaiacol by laccase of white-rot basidiomycete Coriolus versicolor. Appl. Microbiol. Biotechnol., 45, 434-439.

LIN J.E, WANG HY, AND HICKEY R.F. 1993. Degradation kinetics of pentachlorophenol by Phanerochaete chrysosporium. Biotechnol. Bioeng.,35, 1125-1134.

LIU S., SULFITA J.M. 1993. Ecology and evolution of microbial populations for bioremediation. Trends in Biotech. 11,344-352. 
LUECKING A.D., HUANG W., SODERSTROM-SCHWARZ S., KIM M., AND WEBER W.J.JR.. 2000, Relationship of soil organic matter characterization to organic contaminant sequestration and bioavailability. J. Environ. Qual., 29, 317-323.

LYNCH JM. 2002. Resilience of the rhizosphere to anthropogenic disturbance. Biodegradation, 13, 21-27.

MEULENBERG R, RIJNAARTS H.H.M, DODDEMA H.J, AND FIELD J.A. 1997. Partially oxidized polycyclic aromatic hydrocarbons show an increased bioavailability and biodegradability. FEMS Microbiol. Lett.,152, 45-49.

MOGOLLON L, RODRIGUEZ R, LARROTA W, ORTIZ C, AND TORRES R. 1998. Biocatalytic removal of nickel and vanadium from petroporphyrins and asphaltenes. Appl. Biochem. Biotechnol., 70-72, 765-777.

MULBRY W.W, AND EATON R.W. 1991. Purification and characterization of the $\mathrm{N}$ methylcarbamate hydrolase from pseudomonas strain CRL-OK. Appl. Environ. Microbiol., 57, 3679-3682.

MULBRY, W.W.1998. Selective deletions involving the organophosphorus hydrolase gene adpB from Nocardia strain B-1. Microbiol. Res., 153, 213-217.

NAKAJIMA-KAMBE T, SHIGENOAKUTSU Y, NOMURA N, ONUMA F, AND NAKAHARA T. 1999. Microbial degradation of polyurethane, polyester polyurethanes and polyether polyurethanes. Appl. Microbiol. Biotechnol., 51, 134-140.

NAKAMURA K, TOMITA T, ABE N, AND KAMIO Y.2001. Purification and characterization of an extra cellular poly(Llactic acid) depolymerase from a soil isolate, Amycoatopsis sp. Strain K104-1. Appl. Environ. Microbiol., 67, 345-353.

NANNIPIERI P, AND BOLLAG J-M.1991. Use of enzymes to detoxify pesticidecontaminated soils and waters. J. Environ. Qual., 20, 510-517.

NANNIPIERI P, AND GIANFREDA L. 1998. Kinetics of enzyme reactions in soil environments. In: PM Huang, N Senesi, J Buffle (Eds.) Environmental Particles Structure and Surface Reactions of Soil Particles J. Wiley \& Sons, New York, 449-479.
NANNIPIERI P., BOLLAG J.-M., 1991. Use of enzymes to detoxify pesticide-contaminated soils and waters. J. Environ. Qual., 20, 510517.

NICELL JA. 2001. Environmental applications of enzymes. Interdisci. Environ. Review, 3, $14-41$.

NOVOTNY C, VYAS B.R.M, ERBANOVA P, KUBATOVA A, AND SASEK V. 1997. Removal of various PCBs by various whiterot fungi in liquid cultures. Folia Microbiol., 42, 136-140.

ODA Y, YONETSU A, UTAKAMI T, AND TONOMURA K. 2000. Degradation of polylactide by commercial proteases. J. Polym. Environm.,8, 29-32.

OECD. 1998. Biotechnology for Clean Industrial Products and Processes. OECD, Paris, France.

PIRT S.J. 1965. The maintenance energy of bacteria in growing cultures. Royal Soc. London Proc. Ser. B.,163, 224-331.

POINTING S.B, AND VRIJMOED L.L.P. 2000. Decolorization of azo and tri-phenylmethane dyes by Pycnoporus sanguineus producing laccase as the sole phenoloxidase. World J. Microbiol. Biotechnol.,16, 317-318.

POINTING S.B, JONES E.B.G, AND VRIJMOED L.L.P.2000. Optimization of laccase production by Pycnoporus sanguineus in submerged liquid culture. Mycologia, 92, 139-144.

POINTING S.B. 2001. Feasibility of bioremediation by white-rot fungi. Appl. Microbiol. Biotechnol, 57, 20-32.

POLLAK P, ROMENDER G, HAGEDORN F, AND GELBKE H-P. 1991. In: Elvers B, Hawkins S, Schulz G (Eds) Ullman's encyclopedia of industrial chemistry 5 th edn, vol A17, Wiley-VCH, Weinheim, 363-376.

RAO M.A, SANNINO F, GIANFREDA L, AND BOLLAG J-M. 2003. Oxidative transformation of phenols in aqueous mixtures. Wat. Res.,37, 3205-3215.

REDDY C.A, AND D'SOUZA T.M. 1994. Physiology and molecular biology of the lignin peroxidases of Phanerochaete chrysosporium. FEMS Microbiol. Rev.,, 13, 137-152.

REDDY C.A. 1995. The potential for white-rot fungi in the treatment. of pollutants. Curr. Op. Biotechn.,6, 320-328. 
TOSCANO G, COLARIETI ML, AND GRECO

REID B.J, JONES K.C, Semple K.T 2000. Bioavailability of persistent orgnic pollutants in soils and sediment-a perspective mechanism, consequences and assessement. Environ Poll, 108, 103-112.

ROPER J.C, DEC J, AND BOLLAG J-M. 1996. Using minced horseradish roots for the treatment of polluted waters. J. Environ. Qual., 25, 1242-1247.

ROTHSCHILD L.J, AND MANCINELLI R.L. 2001. Life in extreme environments. Nature, 409, 1092-1101.

RUBILAR O., DIEZ M.C:, GIANFREDA L. 2006. Transformation of chlorinated phenolic compounds by white rot fungi. Enzyme and Microbial Technology, submitted.

SANNINO F, AND GIANFREDA, L, 2001. Pesticide influence on soil enzymatic activities. Chemosphere, 22,1-9.

SANNINO F, FILAZZOLA MT, VIOLANTE A, AND GIANFREDA L. 1999. Fate of herbicides as influenced by abiotic and biotic mechanisms. Chemosphere, 39, 333-341.

SHI C., DAI Y., XU X., XIE Y. AND LIU Q. 2002. The Purification of polyphenol oxidase from tobacco. Protein Exp. Purif., 24, 515-519.

SICILIANO S.D., GERMIDA J.J.1998. Mechanism of phytoremediation: biochemical and ecological interactions between plants and bacteria. Environm. Review, 6, 65-79.

SINGH C.J. 2002. Optimization of an extra cellular protease of Chrysosporium keratinophilum and its potential in bioremediation of keratinic wastes. Mycopathologia, 156, 151-156.

SUTHERLAND J.B, SELBY A.L, FREEMAN J.P, EVANS F.E, AND CERNIGLIA C.E. 1991. Metabolism of phenanthrene by Phanerochaete chrysosporium. Appl. Environ. Microbiol., 57, 3310-3316.

SUTHERLAND T, RUSSEL R, AND SELLECK M. 2002. Using enzymes to clean pesticide residues. Pesticide Outlook ,13, 149-151.

SUTHERSAN SS. 1999. In situ bioremediation. Remediation engineering: design concepts. CRC Press LLC, Boca Raton.

TORRES E., BUSTOS-JAIMES I., AND LA BORGNE S. 2003 Potential use of oxidative enzymes for the detoxification of organic pollutants. Applied Catalysis B: Environmental., 46, 1-6.
GJR. 2003. Oxidative polymerisation of phenols by a phenol oxidase from green olives. Enzyme Microb. Technol.,33, 47-54.

TREVORS J.T., KUIKMAN P. AND VAN ELSAS J.D.1994. Release of bacteria into soil: cell numbers and distribution. Journal of Microbiological Methods, 19, 247-259.

VAN BEILEN JB, AND LI Z. 2002. Enzyme technology: an overview. Curr. Op. Biotechnol.,13, 338-344.

VAN WYK J.P.H. 1999. Saccharification of paper products by cellulase from Penicillium funiculosum and Trichoderma reesei. Biomass Bioeng., 16, 239-242.

WALTON B.T., HOYLMAN A.M., PEREZ M.M., ANDERSON T.A., JOHNSON T.R.,GUTHRIE E.A.,CHRISTMAS R.F.1994. Rizhosphere microbical community as a plant defense against toxic substances in soils. In Bioremediation Through Rizhosphere Technology ed. T.A. Anderson, J.R.Coats. American Schemical Society: Washington D.C.,82-92.

WARIISHI H, VALLI K, AND GOLD M.H. 1992. Manganese(II) oxidation by manganese peroxidase from the basidiomycete Phanerochaete chrysosporium. J. Biol. Chem.,267, 23688-23695.

WHITELEY C.G, HERON P, PLETSCHKE B, ROSE P.D, TSHIVHUNGE S, VAN JAARSVELD F.P, AND WHITTINGTONJONES K. 2002. The enzymology of sludge solubilisation utilising sulphate reducing systems. Properties of proteases and phosphatases. Enzyme Microbial. Technol.,31, 419-424.

WILSON S.C., JONES K.C. 1993. Bioremediation of soil contaminated with polynuclear aromatic hydrocarbons (PAHs); a review. Environ. Pollut. 81:229-249.

WYATT J, AND KNOWLES C.1995. Microbial degradation of acrylonitrile waste effluents: the degradation of effluents and condensates from the manufacture of acrylonitrile. Int Biodeterior. Biodegr., 35, 227-248. 